\title{
Principles of Organization of Creative Clusters
}

\author{
Igor Hriptulov \\ The Smolensk State Institute of Arts \\ Smolensk, Russia \\ E-mail: hriptulovigor@gmail.com
}

\author{
Julia Gnezdova \\ The Smolensk State Institute of Arts \\ Smolensk, Russia \\ E-mail: Iuliy_67@mail.ru
}

\begin{abstract}
The paper analyzes the formation of creative clusters, where young artists come to abandoned industrial spaces, transforming them into productive zones. The relevance of the study lies in the fact that the creative economy is one of the most dynamic sectors of world trade in goods and services, whose annual growth since the early 2000 s averaged 8.7\%. At present, it is understood that Russia needs to develop as one of the leading states and an equal member of the world community, not merely as a raw materials resource. This is possible only by changing the national priority of the country's development to emphasize culture. Today, the "creative class" in Russia is not sufficiently large or developed so such services are often imported. Even though these are generally cheap, the total imports exceed exports by more than two times.
\end{abstract}

Keywords-culture; state; cultural policy; sphere of culture and art; creative clusters

\section{INTRODUCTION}

Creative industries are the consolidation of creative and intellectual resources into a "creative product". A group of creative clusters can often be found in abandoned industrial territories of a city; thus, the city is also transformed. Inside the cluster, there is a common, specific, open creative environment for communication and cooperation. New networks of relationships are formed, on the basis of which there is an exchange of ideas [1]. Creative clusters give new life to abandoned territories, which then become more attractive to young people and they begin to live in these spaces. Creative sites always offer an attraction for tourists since many people go to visit the cultural, artistic spaces while traveling. Creative clusters provide new jobs for young people and become points of interest, which positively affects the development of youth and creativity, and reduces migration. Therefore, creative clusters can become hubs that pull together different practices, branches, and links of the cultural process into one place [2]. The work and development of creative clusters lead to a general result: the development of infrastructure, employment and jobs for young people, the opportunity to implement creative initiatives, the influx of tourists, the design of the urban environment, the enriching of urban spaces, and the renting of empty factories.

The purpose of this article is to analyze the existing scientific literature and the results of this study of the creative clusters development in Russia - an analysis of the prerequisites for the emergence of creative platforms, and the construction of a periodization of the history of their formation, evolution, and status to date. The following methods were used in the study of creative clusters: analysis of official statistics, sociological research, and document analysis.

The authors focused their attention on the development of creative clusters in Russian cities. The primary focus was on the foundation, development, and functioning of creative platforms in Moscow and St. Petersburg, which are considered pioneers in the development of creative clusters in Russia, as well as in smaller but no less important cities Yekaterinburg, Ulyanovsk, Novosibirsk, Yaroslavl, Krasnoyarsk, Vladivostok, Krasnodar, Ivanovo, and Kazan. The experience of other countries (the UK, Germany, and Sweden) was also reviewed in the analysis. Numerous publications and documents, as well as the authors' own research describing the activities of creative platforms in different cities of Russia, became an important component of the empirical base of the research.

\section{PECULIARITIES OF FUNCTIONING OF CREATIVE CLUSTERS ABROAD}

Due to the difference in cultural policy and local contextual factors currently, it is necessary to describe different models of development of creative industries. In the most general terms, as a result of the analysis of the literature on the development of creative industries, four main models of the development of creative industries can be distinguished [3]. The characteristics of each model are presented in "Table I": 
TABLE I.

CHARACTERISTICS OF CREATIVE INDUSTRIES MOdELS

\begin{tabular}{|l|l|l|}
\hline \multicolumn{1}{|c|}{ Model } & \multicolumn{1}{|c|}{ Policy } & \multicolumn{1}{c|}{ Accents } \\
\hline USA & $\begin{array}{l}\text { The separation of the spheres of art (culture) and entertainment industries. } \\
\text { The limited role of cultural policy in the development of creative } \\
\text { industries }\end{array}$ & $\begin{array}{l}\text { The development of creative cities. } \\
\text { The role of tourism in labor mobility } \\
\text { as a source of urban growth. }\end{array}$ \\
\hline European & $\begin{array}{l}\text { Cultural significance and mission of creative industries. } \\
\text { Implementation of a broader strategy of the social value of cultural goods } \\
\text { to a wide range of consumers. }\end{array}$ & $\begin{array}{l}\text { The prominent role of cultural tourism } \\
\text { in the development of cultural } \\
\text { industries. }\end{array}$ \\
\hline $\begin{array}{l}\text { Asian (China - Hong } \\
\text { Kong, Shanghai) }\end{array}$ & $\begin{array}{l}\text { The predominance of forms of creative industries which attach special } \\
\text { importance to the role of national socio-cultural, and political factors. }\end{array}$ & $\begin{array}{l}\text { Concentration of the main array of } \\
\text { creative industries around information } \\
\text { technology. Focus on domestic and, to } \\
\text { agrowing extent, foreign markets. }\end{array}$ \\
\hline $\begin{array}{l}\text { Developing countries } \\
\text { (South America, South } \\
\text { Africa, Caribbean) }\end{array}$ & $\begin{array}{l}\text { The preservation and maintenance of cultural heritage. } \\
\text { Reducing poverty. } \\
\text { Improvement of infrastructure in the service sector. }\end{array}$ & $\begin{array}{l}\text { There is no emphasis on the } \\
\text { technocratic component of the } \\
\text { creative industries. }\end{array}$ \\
\hline
\end{tabular}

World clusters come in different sizes - from the larger areas of Hollywood (Los Angeles area), Indian cinema center of Bollywood (Mumbai area, former Bombay), Silicon Valley, and Emscher Park (industrial culture park in the center of the Ruhr basin) - to the smaller scale of urban buildings that have changed from their traditional purpose in "Table II" [4] [5].

TABLE II. FOREIGN CREATIVE CLUSTERS

\begin{tabular}{|l|l|}
\hline \multicolumn{1}{|c|}{ Name } & \multicolumn{1}{c|}{ Description } \\
\hline $\begin{array}{l}\text { Bruman } \\
\text { The United } \\
\text { Kingdom }\end{array}$ & $\begin{array}{l}\text { The cluster is located in London's East End as a University } \\
\text { galleries and center of culture and art. It accommodates art } \\
\text { production companies, bookstores and publishers, cultural } \\
\text { centers, and offices of a variety of creative enterprises. }\end{array}$ \\
\hline $\begin{array}{l}\text { Ruhr } \\
\text { region, } \\
\text { Germany }\end{array}$ & $\begin{array}{l}\text { Home to 5.3 million people, there are five operas and five } \\
\text { universities. It acts as "the cultural capital of Europe". }\end{array}$ \\
\hline $\begin{array}{l}\text { Lithuanian } \\
\text { city of }\end{array}$ & $\begin{array}{l}\text { It restored and transformed the "House over the river" into } \\
\text { an incubator of the arts. Over time, the House became the } \\
\text { center of attraction for the local Bohemia and gave } \\
\text { impetus to the development of the city. Its impact on the } \\
\text { cultural, economic, and social life went beyond the limits } \\
\text { of Vilnius and even Lithuania. }\end{array}$ \\
\hline $\begin{array}{l}\text { Botkyrka }- \\
\text { small } \\
\text { town near } \\
\text { Stockholm, main social effects that have occurred due to the } \\
\text { Sweden }\end{array}$ & $\begin{array}{l}\text { implementation of their creative cluster: a greater demand } \\
\text { for real estate, a significant increase in employment and } \\
\text { opportunities for work, an increase in employment in the } \\
\text { creative industries, and schools training better teachers. } \\
\text { Today, the reputation of this municipality is very high. } \\
\text { Private capital was also attracted. One of those companies } \\
\text { decided to build the largest amusement Park in Northern } \\
\text { Europe here, in which they plan to invest 1.2 billion } \\
\text { Swedish kronor (5 billion rubles). The opening of a theme } \\
\text { park will create numerous jobs for Botkyrka residents. }\end{array}$ \\
\hline
\end{tabular}

All models of creative industries are characterized by cluster-type development trends. Creative industries utilize creative and intellectual resources in "creative products". Thus, in unclaimed industrial territories of the city, zones containing a collection of clusters are transformed also. Inside the clusters, there is a common, specific, open creative environment for communication and cooperation. New networks of relationships are formed, based on which there is an exchange of ideas.

The rise of creative clusters in Europe is due to the emergence of a number of acute social problems in connection with the economic crisis. To solve the problems of unemployment, growing crime rates, and migrant populations, the first projects were implemented to create creative clusters, considering the resources that were already available in the area in the form of representatives of the creative class and the abandoned industrial spaces. To these were added external resources in the form of experts and managers.

One of the features of the European approach to the organization of creative clusters is that it takes place throughout the city, with strong support from the civil authorities and businesses. The main benefits of the organization and development of creative clusters for cities and states are youth employment, transformation of abandoned territories into creative communities, the creation of competitive products, the creation of tourist attractions, the solution of social problems, and the reduction of public discontent.

\section{EXPERIENCE IN CREATIVE CLUSTERS ORGANIZING IN RUSSIA}

Creative clusters give a new life to neglected areas, which become suitable for young people who then settle in them. Creative sites always create an attraction for tourists, as many people go to visit cultural and creative sites. Creative clusters also generate new jobs for young people and become points of attraction, which positively influences the development of youth, creativity, and reduces migration away from the region [6]. Therefore, creative clusters can be seen as centers, pulling together in one place different practices, branches, and links of the cultural process. The development of creative clusters leads to a common result which is working in general for the entire region: infrastructure development, employment and jobs for young people, the opportunity to implement creative initiatives, an influx of tourists, a redesigning of the urban environment, reviving the territories, and renting of empty spaces. The undisputed leader in the production and capacity of cultural clusters is Moscow. Thousands of square meters of creative industries and new forms of cultural life in the capital appeared in the space of former industrial plants. Especially since 2012, creative clusters have come to other regions. At the moment, creative clusters are actively developing in Ulyanovsk, Kostroma, Krasnoyarsk, Novosibirsk, Ekaterinburg, Ivanovo, Vladivostok, Kaliningrad, Kazan, Tyumen, and Yaroslavl in "Table III" [7]. 
TABLE III. CHARACTERISTICS OF CREATIVE AREAS OF RUSSIA

\begin{tabular}{|c|c|c|c|c|}
\hline Name & Type & Financing & Mission & Known products of activities \\
\hline 1 & 2 & 3 & 4 & 5 \\
\hline $\begin{array}{ll}\text { Loft "Trava } & \text { (Grass)", } \\
\text { Novosibirsk } & \\
\end{array}$ & Creative cluster & Private & Creation of the art industry & $\begin{array}{l}\text { Nights of museums, city } \\
\text { festivals }\end{array}$ \\
\hline MTBTS "Pilot", Krasnojask & $\begin{array}{l}\text { Multifunctional } \\
\text { creative platform }\end{array}$ & State & Socialization and self-realization of youth & $\begin{array}{l}\text { Non-museum nights, New } \\
\text { Year's art, flea market, graffiti }\end{array}$ \\
\hline $\begin{array}{l}\text { Creative Space, Rostov-on- } \\
\text { Don }\end{array}$ & $\begin{array}{l}\text { Cultural and } \\
\text { Business Center }\end{array}$ & Private & $\begin{array}{l}\text { Infrastructure for work and leisure. } \\
\text { A democratic environment } \\
\text { communication, teamwork. }\end{array}$ & $\begin{array}{l}\text { Space style, quality and } \\
\text { number of tenants }\end{array}$ \\
\hline $\begin{array}{l}\text { Cultural space "Kamenka", } \\
\text { Krasnoyarsk }\end{array}$ & Loft-project & State & $\begin{array}{l}\text { Support of gifted and talented youth in the } \\
\text { field of creative and art business. }\end{array}$ & $\begin{array}{l}\text { Cultural space, festivals, and } \\
\text { repairs }\end{array}$ \\
\hline 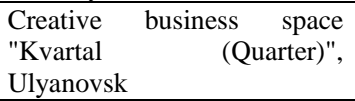 & $\begin{array}{l}\text { Multifunctional } \\
\text { creative platform }\end{array}$ & State & $\begin{array}{l}\text { Creation of a model of work with creative } \\
\text { entrepreneurs and the creative class }\end{array}$ & $\begin{array}{l}\text { Program "Cadres of a new } \\
\text { culture" }\end{array}$ \\
\hline $\begin{array}{l}\text { Center for Contemporary Art } \\
\text { "Oblaka (Clouds)", Ufa }\end{array}$ & $\begin{array}{l}\text { The Center for } \\
\text { Contemporary Arts }\end{array}$ & Private & $\begin{array}{l}\text { Supervision and establishment of resident } \\
\text { companies }\end{array}$ & $\begin{array}{l}\text { Formation of the Creative } \\
\text { Class }\end{array}$ \\
\hline TEXTIL, Yaroslavl & Cultural Center & Mixed & $\begin{array}{l}\text { Establishment of an independent cultural } \\
\text { center in the city }\end{array}$ & City weekend \\
\hline $\begin{array}{l}\begin{array}{l}\text { Cultural center } \\
\text { (Change) Kazan }\end{array} \\
\end{array}$ & Cultural Center & Private & $\begin{array}{l}\text { Popularization of contemporary art and } \\
\text { science knowledge }\end{array}$ & $\begin{array}{l}\text { Summer and winter book } \\
\text { festivals, art criticism lecture. }\end{array}$ \\
\hline ZARYA, Vladivostok & $\begin{array}{l}\text { Contemporary Art } \\
\text { Center }\end{array}$ & Private & $\begin{array}{l}\text { Present the best in Russian contemporary } \\
\text { art }\end{array}$ & Graffiti \\
\hline NMLOFT, Ivanovo & Loft-project & Private & $\begin{array}{l}\text { Work with urban communities and new } \\
\text { developments. }\end{array}$ & Terrace and containers \\
\hline STATION, Kostroma & $\begin{array}{l}\text { Multifunctional } \\
\text { creative area }\end{array}$ & Private & $\begin{array}{l}\text { Presentation of art products and their } \\
\text { promotion }\end{array}$ & Summer Residence \\
\hline
\end{tabular}

The development of creative clusters in Russia can be associated not only with the solution of socio-cultural or economic problems, but also with the creation of conditions for increasing the competitiveness of cities and regions.

\section{CONCLUSION}

Creative industries have become a priority for the development of Russia as a modern country which can confidently look to the future through developing not only natural but also creative resources [8] [9].

Intangible benefits of creative clusters include:

- Development and popularization of contemporary art.

- The attraction of creative youth, increasing the competitiveness of the city.

- Development of social capital.

- Transformation of abandoned premises and adjacent territories into a new creative urban environment.

- Tourist attractions.

- Increased business opportunities.

- Behavioral and attitude changes in city residents.

- Cultural exchanges.

- Volunteer movements.

- Creative education.

- Development of responsibility for their actions among young people.

- Formation of communities.
Thus, in Russia, there is a huge resource, related both to the drive for cultural consumption, and to amateur creative activities. The cultural industries still have much potential to develop. At the same time, creating an attractive environment for the creative class in Russia is the most important challenge in terms of both attracting and retaining this primary resource of modern development [10]. The work and development of creative clusters lead to a general result: the development of infrastructure, employment and jobs for young people, the opportunity to implement creative initiatives, the influx of tourists, the design of the urban environment, the ennobling of territories, and the rent of empty factories.

\section{REFERENCES}

[1] M. B. Gnedovsky, Creative industries: a political call for Russia [Electronic resource] / M.B. Gnedovsky//Domestic notes: the magazine for slow reading. - No. 4 - [Access mode]: http://www.strana-oz.ru/2005/4/tvorcheskie-industrii-politicheskiyvyzov-dlya-rossii

[2] E. Zelentsova, E. Melvil, Creative industries: Russian profile [Electronic resource]: The Creative Compass project - 2012. [Access mode]: http://creativeindustries.ru/uploads/userfiles/file/CI_Russian_profile_ RU_.pdf

[3] D.E. Milkov, Development of the creative industries: aspect of the international cooperation//Cultural diversity, development and globalization: By results of discussions of a round table (Moscow, on May 21, 2003). - M.: RIK, 2003, pp. 103-107.

[4] Website of the British Department of Culture, Media and Sport [Electronic resource]. Access mode: http://www.culture.gov.uk.

[5] Clusters the portal devoted to the creative industries and clusters [Electronic resource]. Access mode: http://www.creativeclusters.com

[6] Yu.S. Milliyeva, Experience of the organization of creative clusters in Russia / Yu.S. Milliyeva//Svobodny Avenue: electronic collection of materials of the international conference of students, graduate students and young people scientific / Modern creative and 
kulturotvorchesky technologies: theory and practice. - Krasnoyarsk, 2015, pp. 43-44.

[7] Summary database on clusters of Russia [Electronic resource]: the database contains data on all clusters of Russia. - Access mode: http://www.economy.gov.ru/minec/activity/sections/innovations/polit ic/doc201001081707

[8] V. Bykovo, Interview. Development of creative clusters in Russia with M. Gnedovsky [Electronic resource]. [Access mode]: http://mediahubble.ru/blog/Kreativnye-industrii/94/Razvitietvorcheskikh-klasterov-v-Rossii.html

[9] K.A. Kirsanov, Creative and heuristic management and inventive art [Electronic resource] / K.A. Kirsanov//Science of science: online magazine. - No. 4, 2011. [Access mode]: http://naukovedenie.ru/sbornik9/9-6.pdf.

[10] A. Lichutin, Theses on cultural clusters. // Ecology of Culture No. 2 (45) of 2008: Newsletter. The proceeding edition (it is published since 1997) / Hl. edition L.E. Vostryakov, Arkhangelsk: Committee on the culture of the Arkhangelsk Region, 2008, 108 p. 